\title{
A Management Model for
}

\section{Professional Wholeness}

M De Villiers

D Cur (Student)

Rand Afrikaans University

\&

\section{Muller \\ D Cur}

Professor : Department of Nursing Sceince

Rand Afrikaans University

\&

M Poggenpoel Ph D

Professor : Department of Nursing Science

Rand Afrikaans University

\section{The irony is that nurses are in a "caring" profession, but when it comes to them as individuals, very little caring is effected.}

\section{Abstract}

The purpose of this article is to describe a management model for professional wholeness. A theory generating research design was followed. Based on this model the consequences of management could be a state, which varies dynamically between minimal and maximal professional wholeness. A list of descriptive words was developed to generate qualitative indicators of professional wholeness.

\section{Overview}

The negative experiences reflected by nurses (Muller \& Coetzee, 1990) echo a statement about conventional and prevailing management models. The essence of the inadequacy of general management models in resolving nursing management dilemmas is not so much in their basic framework but in their central motive. For example, Weber's (1947) model of bureaucracy was designed to give "legitimate authority" to bureaus, which in turn had to benefit the economic interests of the community and reinforce capitalism. Likert's (1961:293) model endeavours to relieve the deterioration in manufacturing, production and control, by designing a formula for a high producing organisation. Vroom's (1974) normative model focuses on decision making for better production results.

A myriad of classical and contemporary management models have undeniably moulded general management thought as well as nurse management practice. The significance of these models is not denied, but their relevance to present day nursing management situations is certainly questioned.) In the search for clarification of the problems and crises in the nursing environment, managers and researchers alike tend to disregard the obvious fact that these models were not designed for the nursing scenario. The insufficiency of these models to adequately address the nurse manage-

\section{Opsomming}

Die doel van hierdie artikel is om ' $n$ bestuursmodel vir professionele heelheid te beskryf. 'n Teorie-genererende navorsingsontwerp is gevolg. Gegrond op hierdie model kan die gevolge van bestuur wissel van ' $n$ toestand tussen minimale en maksimale professionele heelheid. ' $n$ Lys van beskrywende woorde was ontwikkel om kwalitatiewe aanwysers van professionele heelheid te genereer.

ment situation is thus self-evident The irony is that nurses are in a "caring" profession, but when it comes to them as individuals, very little caring is effected. In actual fact with the application of the various managerial models, the innate caring ability, which is vital in nursing interaction, is brutalised, instead of being nurtured, cultivated and developed.

Nurse managers need to urgently change course away from general management models. If they relentlessly persist with their application to the nursing environment, whilst their main focus is on all things else but the crucial service and caring aspects unique to the nursing environment, the looming crisis in our midst will prevail.

In this study an attempt has been made to contribute towards a change in direction for nurse management and to construct a model which deliberately diverges form existing general management frameworks by applying a nursing theory as the point of departure - which can then enable us to address the nursing organisation as a unique organisational entity, with equivalent unique interactional paradigms.

The nursing theory framework and approach employed in designing this model is the "Nursing for the Whole Person Theory" (NWPT), developed by the Oral Roberts University Anna Vaughn School of Nursing (1990). The intrinsic 
service and wholeness orientation of this theory was utilised as metaphor to construct a management model, which will enable nurse managers to strive towards professional wholeness (Randse Afrikaanse Universiteit, Departement Verpleegkunde, 1991).

The functional approach employed in this study aims at providing quality patient care. The achievement of the research objective, namely to generate and describe a nurse management model for professional wholeness, will be addressed in this article.

\section{Research Design and Method}

A contextual research design was employed for exploring, describing and generating the model. The type of model, which was generated, is regarded as "middle-range" and "situation-relating" theory. According to the classification of Walker \& Avant (1983) the model is "middle-range theory" due to the utilisation of the global framework of the NWPT as grand theory, to meet the needs which exist in the nurse management domain for a model based on the wholeness approach. The model was further constructed as "situation-relating theory" according to Dickoff, James \& Wiedenbach's (1968) classification, due to the description of dynamic relationships between wholeness and management within the context of the nurse management situation. The management model for professional wholeness was accomplished by employing the theory-generating approach of Dickoff, James \& Wiedenbach (1968) whereby the model was developed progressively by following the three phases of factor isolation, factor relation, up to the level of situation relation.

\section{Phase 1: Factor Isolation}

In factor isolation the concepts relating to management interaction must first be identified and then redefined within the context of the model. The two steps involved in factor isolation are therefore the identification and defining of concepts. Concept identification was effected by a survey of the literature and by applying a survey guide to analyse various categories. The survey was done by means of a literature investigation of existing management models and specific models were then selected for closer scrutiny. These models were deliberately selected from three main schools of managerial and organisational approach and the systems approach. A total of fourteen models were selected.
Three of the selected structural models are general management models and two are nurse management models. The following five structural models were selected:

- Legitimate authority and bureaucracy" (Weber, 1947)

- General principles of management (Fayol, 1947)

- $\quad$ Macro perspective (Robey, 1982)

- Nursing administration

(DiVincenti, 1989)

- Nursing leadership and management (Douglass, 1988)

Five behaviour models were selected, two from general management and three from nurse management. The following behaviour models were selected:

- Supportive relationships (Likert, 1961)

- $\quad$ Participate nursing management (Porter O' Grady, 1986)

- Normative model of managerial decision making (Vroom, 1974)

- $\quad$ Nurse retention. A planned process (Vogt, Cox, Velthouse \& Thames, 1983)

- Job-satisfaction and plan to stay or leave for registered nurses (Walek, 1979)

Four systems models were selected, three of which from general management and one from nurse management, namely:

\section{- Social systems model for organi- sation (Beer, 1980) \\ - Ecological theory applied to organisations (Sratton \& Flynn, 1980) \\ - Integrative mechanisms (Miles, 1975) \\ - Systems model for nursing mana- gement (Gillies, 1989)}

In a pilot investigation, the Legitimate authority and bureaucracy (Weber, 1947) model was used to verify that the researcher was employing the categories of the survey guide correctly in researching the contents of the models. An independent expert and the researcher respectively explored the contents of the said model, according to the categories of the survey guide. A supervisor then qualitatively compared the correlation of the data generated by the researcher and the independent expert. By means of this comparison it was established that the researcher was able to reflect the content of the models precisely and employ the categories of the survey guide accurately. Once the integration had been done, the survey guide of Dickoff, James \& Wiedenbach
(1968) was employed to reflect the approach and content of each model without interpreting it. Consequently, what has been reflected in these categories are the direct opinion of the author of a specific model and thus not the sentiments of the researcher.

The six main categories of the survey guide were employed in the form of questions. These "questions" were used to reflect the content and views of a selected model about the following:

$\square \quad$ The agency (the manager);

- The recipient (the nurse and patient or client);

- The framework (the framework within which activities are executed);

$\square \quad$ The terminus (the end result of activities);

The procedure (the procedure or process that will lead to the end result);

The dynamics (the motivation behind activities).

The data collected was handled as raw data and processed for content analysis. The content analysis protocol of Wilson (1989) was applied because the technique is suitable for processing qualitative raw data collected from this model survey. The data was categorised according to three main categories, namely structural models, behavioural models and systems models. The six categories of the survey guide were used as secondary categories and emanating from these categories tertiary categories were developed. A manifesting analysis of the survey data examined the semantic content. The latent analysis examined the meaning and implications through the interpretation of statements (Wilson, 1989). The literature and the study leaders verified the content validity of the analysis.

The analysis was also confirmed by examining the semantic meaning of words. Words and terminology in the raw data were underlined and listed according to the categories. The underlined descriptive words were tabled for comparison. The acceptance or rejection of the identified statements was then debated, based on their congruency with the philosophy and basic assumptions of the NWPT.

The three-step method of Wandelt (Wandelt \& Stewart, 1975) was applied to do a systematic investigation of the semantic description of the ultimate concepts and terminology. The definitions of these concepts, as obtained from dictionaries and subject literature, were listed without accepting any one in particular. In the first step the general or dictionary definitions were investigated. 
Explanations of concepts were noted. The meaning of a concept, as specified within the discipline of management and nursing were reproduced as "subject related" definitions. In the second step, pertinent definitions were investigated for the meaning of concepts where they were employed within a specific situation or circumstance in nurse management. The third step entailed "for instance" definitions where the meaning of a concept is illustrated by using an observable real life example in nurse management to explain the use of a concept. Examples or cases must be conceptualised to explain what is meant or not meant by a concept. Two types of examples emerged from the analysis. The definitions in the structural, behavioural and systems models were the related cases because they illustrate what was not meant with the central concepts. The management perspective founded on the approach of the NWPT was accepted as the model case due to its illustration of what is meant by the concepts. At this stage the conceptual framework for the new model crystallised. Provisional definitions were formulated and were subsequently refined after exposure to expert opinion.

\section{Phase 2: Factor Relation}

In this phase the relationship between the identified factors was delineated as statement and logical arguments. The categories of the survey guide and the assessment framework of the NWPT were utilised to describe the relationships in the form of propositions and assumptions.

\section{Phase 3: Situation Relation}

Based on the information and data collected from the previous phases, a provisional model was now constructed. The concepts and statements were consolidated to form the overall picture. With the construction of the new model a particular bond is depicted between the assumptions of the NWPT and manage-ment interactions. A diagram was constructed to portray a visual image of the conceptualised model. The tentative model was then put through a process of refinement. This process of refinement consisted of a critical evaluation and discussions with domain experts (multicultural representative; three nursing theorists: six general personnel managers; twenty-six general manage-ment consultants, and seven nurse managers).

The six criteria of Hardy (1973) were applied to structure the evaluation, namely:

$\begin{array}{ll}\square & \text { meaning and logical value; } \\ \square & \text { operational and empirical value; } \\ \square & \text { generality; } \\ \square & \text { contribution towards under- } \\ & \text { standing; } \\ \square & \text { prediction possibilities; } \\ \square & \text { pragmatic value. }\end{array}$

The extent to which the model succeeded in these objectives was descriptively evaluated, after which certain statements were reviewed, refined and adjustments made. Hypotheses were formulated by using the relationship typology of Hardy (1973) where logical inferences are made and relationships are debated on the basis of "if then... Therefore..." arguments (Bandman \& Bandman, 1988). The following nine relationship types were formulated

- symmetrical (if $A$ then $B$; if $B$ then $A$ );

asymmetrical (if $A$ then $B$; but if no $A$, no conclusion about $B$ );

- causal (if $A$, always $B$ ); probalistic (if $A$, probably $B$ );

$\square$ time order (if $A$, later $B$ );

$\square$ concurrent (if $A$, also $B$ );

- sufficient (if $A$, then $B$, regardless of anything else);

$\square$ conditional (if $A$, then $B$, but only if C);

$\square$ necessary (if $A$ and only $A$, then $B$ )

\section{Model Description}

"A MANAGEMENT MODEL fOR PROFESSIONAL WHOLENESS (MPW)"

is described, as reflected in figure one.

The framework in which management interaction transpires is the nursing organisation with an internal and external environment. The agent is the nurse manager and the recipients are the nurse employee and the patients or clients. The determinants of management are embedded in the organisational environment. The characteristic means of interaction are wholeness management strategies and processes. The terminus of wholeness management is maximal professional wholeness and the possible consequences of management vary on a continuum between minimal and maximal professional wholeness. The dynamic energy motivating wholeness

\section{Figure 1 Management model for professional wholeness}

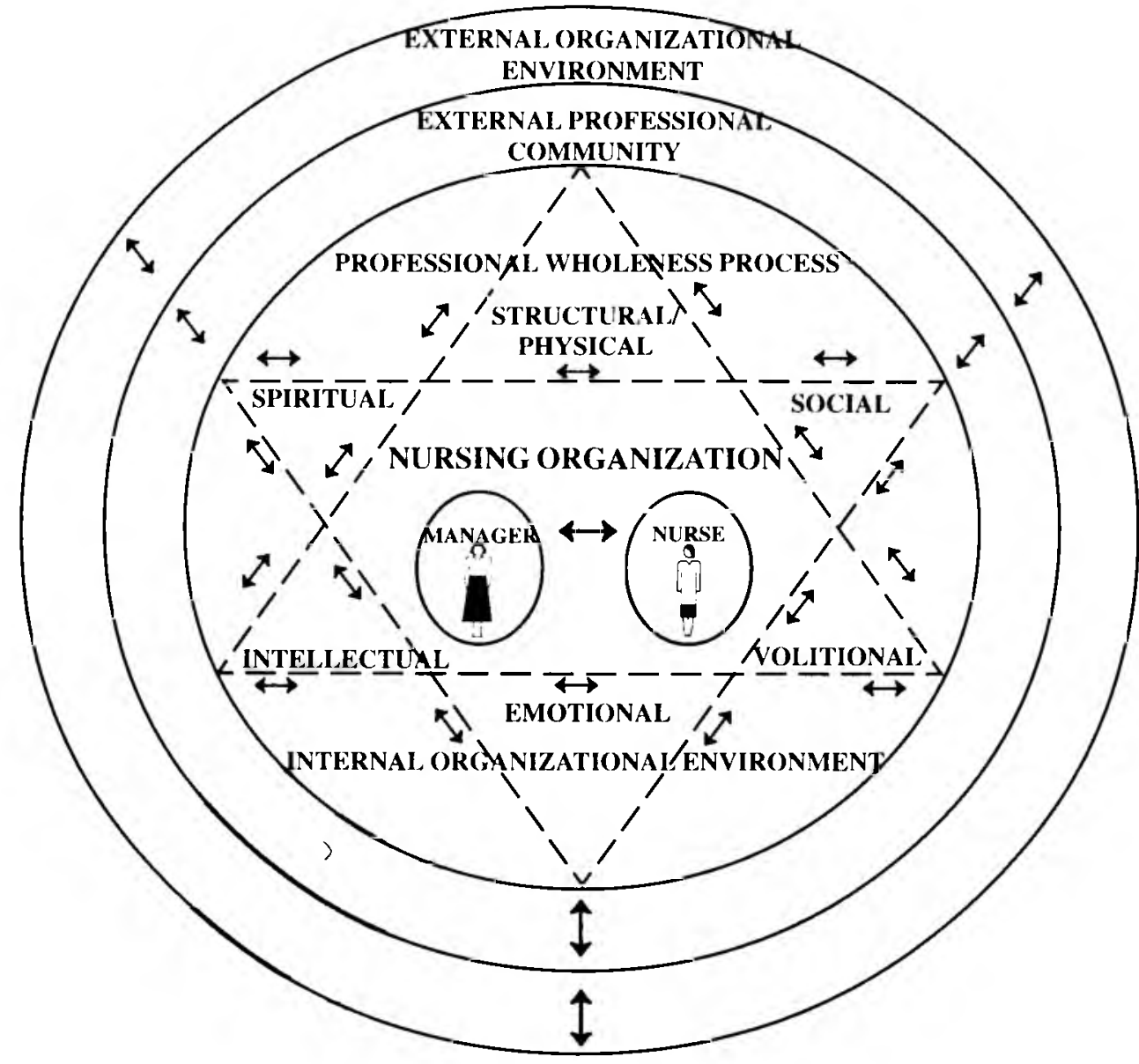




\section{The Organisa- tional Framework}

The concept "organisation" will be discussed primarily due to the critical framework it provides for management interaction. Within a wholeness perspective the organisation is defined as a complex and dynamic corporate body which functions purposely in an integrated and co-ordinated manner on a structural/physical, psychological, spiritual and social basis in the search for organisational is unique but also an integral part of the community in which it functions and forms part of the work or professional environment of its members. The internal environment of the organisation is structural/physical, psychological and social by nature whilst the external environment is physical, psychological, spiritual and social by nature. The organisation as a whole is continuously moulded by its internal and external environment. An organisation, as a professional entity, operates within the external environment of individuals, but as a corporate body it also has its own internal and external environment. The margin delineating the internal and external environment of the organisation is permeable and demarcated by its physical framework. The internal environment of the organisation is therefore an external, internal environment because it is external to the individual member but internal in terms of the demarcation by its own physical organisational framework.

Between the internal and external environment of the organisation there are reciprocal, complementary, corresponding, comparative and interrelated interactions. The internal environment of the organisation is a micro replica of the broader external environment. The organisation's professional wholeness status is determined by the interactions within its internal environment on the one hand and its interactions with the external environment on the other hand. The promotion, maintenance and restoration of organisational wholeness require the actualisation and mobilisation of all the resources in the internal and external organisational environment. The organisation as a whole functions in an integrated structural/physical, psychological, spiritual and social manner in its pursuit of wholeness.

In this article the focus is on the internal organisational environment. The health care organisation's mission necessitates the rendering of a purposeful and dynamic service to assist individuals,

\section{The internal environment of the organisation is a micro replica of the broader external environment.}

families and communities in the promotion, maintenance and restoration of health. The very reason for the existence of an organisation lies with its mission. Within the organisation there are continuous processes and interactions to achieve the organisational mission. The organisational entity consists of two basic incorporating sectors, its physical structure and the persons who interact with the organisation. A physical structure without members would be like an empty shell and individuals without a physical structure, is organisationally incapacitated. The physical framework and the human beings within that framework must be in harmony with each other, otherwise chaos and destruction will result. The interaction between the organisational sectors does not manifest itself in an isolated manner but rather in an integrated, co-ordinated and dynamic configuration.

The physical structure combined with the individuals relating with an organisation communally reflect the professional wholeness status of the organisation. The physical framework of the organisation is the accumulated of various concrete and tangible structural aspects and features. These involve the physical, material and product or service structures of the organisation. As a professional wholeness dimension the physical framework is integrated with and influenced by all the other dimensions and portrays the physical image of the organisation. The wholeness status of the physical framework of the organisation can be appraised qualitatively by considering the manifestation of particular characteristics. Each organisation has some kind of physical structure, however, basic or flexible it might be. The physical structure can vary from huge buildings or mobile clinics to even more basic structures such as clinics in the shade of an African tree. The physical structure provides an essential framework for the organisation's transactions, interactions and operations and plays a critical role in interactions, perceptions about and the reflection portrayed by the organisation to the external environment.

The material structure of the organisation is reflected by its other capital assets, for example office equipment and transport. The financial aspects are also part of the material structure of the organisation and are reflected by its budget, cash flow, income and expenses. It also entails the consuming profile of the organisation, which is reflected by the use of different materials (such as fuel and other consumables). The product and or service orientation of the organisation defines the foundation for its physical existences. The product structure of the organisation is reflected by various materials or products, for example medicines and prosthesis. When the mission of the organisation is founded on a service orientation (for example nursing services and educational services), the service structure is portrayed by the type and quality of the service rendered.

The human dimension of the organisation is personified by the individuals who relate with the organisation and are referred to as "members". The individuals, whether termed employees, managers, directors, shareholder, clients or patients, function parallel to the physical framework of the organisation and together they form the whole organisation. Each member of the organisation is viewed as "person" and therefore regarded according to the following definition: "A person is a spiritual being who functions in an integrated biopsychosocial manner to achieve his quest for wholeness. Each person, though a unique individual, is an integrated member of a family, group and community. The person's pattern of interaction with the internal and external environment determines his wholeness status" (Oral Roberts University Anna Vaughn School of Nursing, 1990, Randse Afrikaanse Universiteit, Departement Verpleegkunde, 1991). There are various members in an organisation that occupies certain positions, who execute certain functions and who fulfil certain roles. Attached to a member's position within an organisation is a mandate for the execution of certain functions.

Central to a member's mandate are the interactions, processes and dimensions of professional wholeness. Regardless of the objective of the organisation the focus of interaction amongst its members must be towards the quest for professional wholeness. In this quest for professional wholeness the nurse manager's mandate requires a specific relationship with the nurse.

The nurse manager within the context of this model has been identified as the 
agent, the person who executes managerial processes and the nurse has been identified as the recipient. The nurse and the manager made critical career and position decisions. Their professional paths converge and diverge within the organisation in a specific way. The nurse made a career decision to qualify for the nursing profession through a professional advancement programme, which enabled him/her to act as facilitator in the nursing mission. The nurse manager, as a qualified nurse, made a career choice by preparing for a managerial position through the expanding of knowledge and abilities of management. The nurse manager chose to serve in a managerial position in an organisation, by which he/she has been given a directive to execute a meaningful managerial service in order to facilitate the accomplishment of the mission of the organisation.

The manager and employee share an organisational (work) environment. The environment of the manager and nurse employee respectively includes his/her own internal as well as external environment. The professional environment (related term: work environment) comprises the internal and external organisational environment and forms part of the manager's and the nurse's own external environment.

Interaction between the internal and external environment of the manager and employee respectively will determine the manager and nurse's personal wholeness state, of which professional wholeness is a specific dimension. The professional experiences (related terminology: work experiences) of the manager and nurse, encompass all the interactions in the organisational environment, which are mirrored in the professional wholeness status of the manager and the nurse.

Both the nurse manager and the nurse are employees of the organisation. This signifies that both the individual member and the organisation made a deliberate choice. The nurse manager and the nurse alike made the choice to avail themselves by applying for a position in the organisation and the organisation has selected them to occupy a specific position, by employing them for the enhancement of its mission and compensating them for the services they render.

From this perspective then, the role of the manager is defined as that of a nurse who serves in a managerial position where he/ she renders a managerial service with the mandate to strive in an integrated manner towards own personal, organisational and professional wholeness, and with the objective to purposefully and dynamically facilitate interactions for the promotion, maintenance and restoration of maximal professional wholeness, in order to accomplish the mission of the organisation.

Equally then, the role of the nurse can be defined as that of a person who serves in a nursing position where he/she renders a nursing service in the mandate to strive in an integrated manner towards own personal, organisational and professional wholeness, and with the objective to purposefully and dynamically facilitate interactions for the promotion, maintenance and restoration of health in order, to accomplish the mission of the organisation.

The managerial position is a service position where "authority" does not signify line and staff authority but a service authority and mandate, namely to strive purposefully and dynamically towards the facilitation of wholeness of employees, the community and the organisation. Thus, the distinctiveness of the manager does not lie in a position of superiority but rather in the managerial service mission and in the leadership of a unique group of people with unique talents. In order to occupy the managerial position, the prerequisites are that the manager must be a specialist on the subject of management and must have skills and abilities to interact purppsefully and dynamically.

Both the manager and the nurse as individuals have own unique bodily/ physical, psychological and spiritual needs, and are outside the organisational environment, integral members of a family, a group and a community. As a manager or a nurse, he/she is thus also an integral part of an organisation and professional community, which again forms part of his or her external environment. In the quest for own personal and professional wholeness the

The manager and employee share an organisational (work) environment. The environment of the manager and nurse employee respectively includes his/her own internal as well as external environment. manager or the nurse contributes not only towards the wholeness of others but towards the wholeness of other employees, the professional community and the organisation. The personal devotion of the manager and the nurse entails the quest for own personal and professional wholeness, enabling them to facilitate the professional wholeness of colleagues, the organisation and the community. The manager and the nurse who experience maximal personal and professional wholeness, have a greater potential to facilitate wholeness and hence to enhance the realisation of the organisational mission.

The managerial service requires leadership, teaching, mentoring, counselling and guidance in the quest for the promotion, maintenance and restoration of professional wholeness. The service mandate necessitates a managerial orientation of identifying with and relating to the employees. The managerial service consequently requires dynamic, goal-oriented mentorship and facilitator skills.

Mentorship as a fundamental leadership paradigm in wholeness management refers to the personal, professional interaction of the manager with the employee. Mentorship focuses the manager on the wholeness of each and every person in the organisation but specifically on the nurse employees. In providing mentorship, the inherent talents of people within the organisation are amplified, enhanced and developed and not suppressed. It is mandatory in the mentorship role that the manager should enhance his/her own qualities relating to appreciation, recognition, acceptance, consideration, flexibility, receptiveness, awareness, sensitivity, observance, attentiveness, cognition, reflection and thoughtfulness. Mentorship as a manner of leadership is founded on mutual respect and signifies goal-directed interaction, guidance to and counselling with employees. On a practical level it means providing opportunities, encouraging nurses to achieve and intensify their inherent potential, abilities and capabilities and to develop the necessary skills enabling them to experience a meaningful organisational relationship. In the mentorship role the manager facilitates professional wholeness of the nurse and the organisation in a co-ordinated manner through the practising of purposeful and dynamic interactional leadership.

Facilitation is considered an essential interactional skill for assisting and serving employees in the attainment of their professional or organisational mandate. Facilitation refers primarily to amplifying, 


\section{The concept "professional wholeness" is defined as a complex, integrated and dynamic professional state, which is structural/physical, spiritual, social, intellectual, emotional and volitional by nature and which can be described qualitatively on a continuum varying between minimal or maximal professional wholeness.}

enabling, assisting and setting in motion the managerial processes. The wholeness managerial strategies of promoting, maintaining and restoring professional wholeness are accomplished through facilitation. With mentorship the nurse manager utilises the wholeness management strategies and processes as interactional paradigm to facilitate professional wholeness.

The organisational community consists of all the formal and informal groups within the organisation. The groups are represented by the various careers within the organisation. The internal nurse community thus forms part of the broader organisational community. The nurse community is composed of nurses, organised in internal groups owing to their identification with the mission of a specific nursing organisation, and in external groups owing to their communal choice of nursing as a career. The internal and external groups of nurses are in interaction with each other, value each other and reflect each other's professional wholeness status. All the factors influence the nurse groups which again are reflected in the professional wholeness status of the organisation.

\section{Professional Wholeness}

The possible consequences of management are reflected on a continuum varying from minimal to maximal professional wholeness. The terminus though, of wholeness management is maximal professional wholeness represented by six equal and interrelated dimensions. The concept "professional wholeness" is defined as a complex, integrated and dynamic professional state, which is structural/ physical, spiritual, social, intellectual, emotional and volitional by nature and which can be described qualitatively on a continuum varying between minimal or maximal professional wholeness. The term "professional" is used instead of related terminology such as "work" or "job". The concept "job" is viewed as referring to a laborious economic activity. "Professional" - in the context of this model - signifies a "special devotion, commitment and service". The concept of professional wholeness is applied to the organisation as well as to all its employees, which include for example the nursing assistant, the professional nurse and the manager.

Maximal professional wholeness is indicated as the terminus of management interaction instead of related concepts such as "job satisfaction" or "quality of work life". Professional wholeness entails much more than mere satisfaction, although satisfaction could be used as an indicator of professional wholeness. Satisfaction per se does not necessarily mean that a person is professionally whole. For example, a person might be extremely satisfied with the job but can suffer emotionally due to worries about a sick child. If this is overlooked it will affect the wholeness status of the organisation. In order to reflect the ideal state of maximal wholeness a person or organisation should indicate maximal professional wholeness dimensions are present in every organisation regardless of its specific orientation, objective and mission.

\section{Professional Wholeness Dimensions and Processes}

Professional wholeness dimensions and processes are two distinctive concepts although closely related. The six integral organisational dimensions and processes of wholeness are identified as structural/physical, intellectual, emotional, volitional, spiritual and social in nature. These dimensions and processes are analogous and parallel although not essentially concurrent with each other. The dimensions constitute the whole whilst the processes facilitate professional wholeness. Within each dimension two kinds of processes are encountered. One, the spontaneous organisational processes which occur naturally without managerial interaction (for example social organisational processes) and two, the wholeness management interactions. Within a particular dimension spontaneous organisational processes are dynamic, integrated and co-ordinated. Within the day-to-day functioning of the organisation they can hardly ever be examined or explored in isolation, because they are reflected as the whole.

The wholeness management process culminates by goal-directed, dynamic management interactions which are structural/physical, spiritual, social, intellectual, emotional and volitional by nature and which function in an integrated, co-ordinated manner as scientific processes in the quest for the promotion, maintenance and restoration of professional wholeness.

The intensity of the management processes is directed by promotional, maintaining and restoration strategies. Promotional strategies are relevant when a moderate state of professional wholeness is reflected, and restoration strategies are relevant when a minimal state of professional wholeness is reflected.

The kind of stategy is directly related to the state of wholeness reflected, for example the intensity of an intellectual management process need not be resorational when the organisation reflects maximal intellectual wholeness, but can rather be maintaining. The professional wholeness status of an organisation is appraised qualitatively by considering the manifestation of particular characteristics. Qualitative indicators are applied to assist in the assessment of the wholeness dimensions. The relationship between management interaction and a particular wholeness dimension of concern can be symmetrical or asymmetrical. Symmetrical interactions occur when the interactions are parallel to the dimension of concern. For example, if minimal social wholeness is reflected by "isolation" then restoration with intensified social interaction such as participation and teamwork should take place. However, symmetrical management interaction need not specifically be relevant to the restoration, maintenance or promotion of the wholeness dimension of concern. In this instance an asymmetrical relationship differ from the dimension of concern. For example, if moderate volitional wholeness is reflected by "disappointment, then promote with emotional interaction "support".

The symmetrical and asymmetrical management interactions relevant to restore, maintain and promote professional wholeness in any specific dimension are not mutually exclusive, but rather dynamic, integrated, multifaceted and goal directed. Multilevel interaction might well be necessary to restore, maintain 
and promote professional wholeness on a particular dimension. The reflection of these multifaceted symmetrical and asymmetrical relationships between dimensions and management interaction results in a matrix as indicated in table one. The managerial skills and abilities are again critically important in the assessment of a situation and in the choice of appropriate interactional paradigms. the direct facilitator of the nursing process whilst the management process facilitates the professional wholeness of the individual nurse. When nurses experience professional wholeness to a significant maximal degree, they have a greater potential to facilitate quality nursing care, and therefore health. Within the physical framework of the organisation there are structural and physical processes. The structural processes are management of the material assets and budgetary, administrative and conservation management.

The physical management processes entail the facilitation of the bodily/physical professional wholeness of the individuals functioning within the organisation. This indicates interaction for the promotion, maintenance and restoration of the bodily/physical occupational health of

\section{Table 1 Individual professional wholeness indicators}

\begin{tabular}{|c|c|}
\hline $\begin{array}{l}\text { PHYSICAL } \\
\text { INDICATORS }\end{array}$ & $\begin{array}{l}\text { SPIRITUAL } \\
\text { INDICATORS }\end{array}$ \\
\hline maximal & maximal \\
\hline $\begin{array}{c}\text { agile } \\
\text { industrious } \\
\text { lively } \\
\text { orderly } \\
\text { comfortable } \\
\text { neat } \\
\text { tidy } \\
\text { vitality } \\
\text { strength } \\
\text { energetic } \\
\text { active } \\
\text { radiant }\end{array}$ & $\begin{array}{c}\text { devoted } \\
\text { committed } \\
\text { loyal } \\
\text { faithful } \\
\text { conscientious } \\
\text { respectful } \\
\text { appreciative } \\
\text { earnest } \\
\text { honest } \\
\text { dignity } \\
\text { integrity }\end{array}$ \\
\hline minimal & minimal \\
\hline $\begin{array}{c}\text { lax } \\
\text { passive } \\
\text { lethargic } \\
\text { indolent } \\
\text { sluggish }\end{array}$ & $\begin{array}{c}\text { dishonest } \\
\text { treacherous } \\
\text { disloyal } \\
\text { betrayal } \\
\text { superficiality } \\
\text { vanity } \\
\text { deceptive } \\
\text { audacity }\end{array}$ \\
\hline
\end{tabular}

The wholeness management process, similar to the nursing process, is a scientific process, applying the activities of assessment, planning, implementation and evaluation. These scientific activities are relevant regardless of which kind of interactions are necessitated. The relationship and interaction between the management process and the nursing process are concurrent dynamic and coordinated.

The wholeness management process indirectly enhances the potential of the nursing process. The individual nurse is

\begin{tabular}{|c|c|}
\hline $\begin{array}{c}\text { SOCIAL } \\
\text { INDICATORS }\end{array}$ & $\begin{array}{l}\text { INTELLECTUAL } \\
\text { INDICATORS }\end{array}$ \\
\hline maximal & maximal \\
\hline $\begin{array}{c}\text { cooperative } \\
\text { tactful } \\
\text { accommodating } \\
\text { diplomatic } \\
\text { humorous } \\
\text { mindful } \\
\text { kind } \\
\text { considerate } \\
\text { courteous } \\
\text { polite }\end{array}$ & $\begin{array}{l}\text { inquiring } \\
\text { exploring } \\
\text { observant } \\
\text { accurate } \\
\text { methodical } \\
\text { systematic } \\
\text { meticulous } \\
\text { creative } \\
\text { innovative } \\
\text { attentive }\end{array}$ \\
\hline minimal & minimal \\
\hline $\begin{array}{l}\text { arrogant } \\
\text { sarcastic } \\
\text { crude } \\
\text { tactless } \\
\text { impolite } \\
\text { harsh } \\
\text { cruel } \\
\text { rude } \\
\text { lonely } \\
\text { offensive } \\
\text { nasty }\end{array}$ & $\begin{array}{c}\text { irrational } \\
\text { foolish } \\
\text { ignorant } \\
\text { unreasonable } \\
\text { argumentative } \\
\text { stubborn } \\
\text { annoyed } \\
\text { impulsive }\end{array}$ \\
\hline
\end{tabular}

related to the physical framework of the organisation, whilst the physical processes are related to the physical status of the individuals within the organisation. Spontaneous structural processes involve the natural structural processes, for example building and material deterioration, resource depreciation and economic influences on the organisation that takes its course.

Structural management processes entail the promotion, maintenance and restoration of the physical structure of the organisation. It will, for example entail

\begin{tabular}{|c|c|}
\hline $\begin{array}{l}\text { EMOTIONAL } \\
\text { INDICATORS }\end{array}$ & $\begin{array}{l}\text { VOLITIONAL } \\
\text { INDICATORS }\end{array}$ \\
\hline maximal & maximal \\
\hline $\begin{array}{c}\text { satisfied } \\
\text { joyful } \\
\text { calm } \\
\text { enthusiastic } \\
\text { sensitive } \\
\text { eager } \\
\text { happy } \\
\text { cheerful } \\
\text { content } \\
\text { gentle }\end{array}$ & $\begin{array}{l}\text { courageous } \\
\text { determined } \\
\text { resourceful } \\
\text { persistent } \\
\text { diligent } \\
\text { discreet } \\
\text { dedicated } \\
\text { receptive } \\
\text { perseverance } \\
\text { realistic }\end{array}$ \\
\hline minimal & minimal \\
\hline $\begin{array}{c}\text { dissatisfied } \\
\text { discontent } \\
\text { sad } \\
\text { irritated } \\
\text { anxious } \\
\text { tense } \\
\text { negative } \\
\text { pessimistic } \\
\text { agitated } \\
\text { phlegmatic }\end{array}$ & $\begin{array}{l}\text { doubtful } \\
\text { indecisive } \\
\text { indifferent } \\
\text { aimless } \\
\text { reckless } \\
\text { listless } \\
\text { opportunistic } \\
\text { possessive }\end{array}$ \\
\hline
\end{tabular}

employees.

The spiritual dimension pertains to intuition, differentiation and judgement between right and wrong. In the organisation this pertains to conscience, laws, regulations, principles, morals, ethics, standards, values and policies. The spiritual management interactions involve policy-making, formulation of standards, disciplining, clarifying mandates and corrective interaction. The social dimension is the reflection of the status of the interpersonal relationships, communication, group affiliation and 
interactions within the organisation. Social management processes pertain to the facilitation of all social interactions, such as team building, interpersonal skills, communication and the generating of group interaction and participation. The psychological ambience of the organisation is reflected individually by persons and communally by groups within the organisation. The psychological dimension of the organisation embodies three interrelated aspects, namely the intellectual (int), emotional (emo) and volitional (vol) dimensions.

The intellectual or "int" dimension is where wisdom, rationality and knowledge prevail. Organisational mission, objectives and orientation are defined in this dimension. The intellectual management processes entail all intellectual activities where deliberation and rational knowledge are required, for example analysis to gain insight into the details as well as the overall vision of the organisation and information processing. To harmonise wholeness in this dimension, intellectual interactions such as analysis, logistics, factuality, training, planning, assessment and evaluation need to be activated. The emotional or "emo" dimension is reflected by the feelings and attitudes in the organisation. These feelings vary in degree. To harmonise the emotional climate in the organisation various promotional, restrorational and maintaining strategies are necessary. The emotional management processes entail empathy, caring, compassion, understanding, patience, acceptance and tolerance. The "vol" dimension is the basic inherent dynamic energy, willpower and driving force that propels the organisation into a specific direction. Volitional management processes are embedded in motivation, inspiration and design-making processes.

\section{Professional Wholeness Indicators and Profiles}

The professional wholeness status of the organisation or individual employee is appraised qualitatively by considering the manifestation of particular characteristics. To express these characteristics value laden descriptive words are applied to assist the manager in appraising the status of the professional wholeness dimensions. The words were chosen based on their general dictionary meaning.

The descriptive words can by no means be more than just an indication of the professional wholeness status. They are not exact measurements of professional

\section{When a person has an exceptionally high social focus his/her inherent talents are a high proficiency in interpersonal relationships and skills.}

wholeness but can rather be viewed as reflections or impressions projected by the dimensions and can therefore merely aid in the conceptualising of the professional wholeness status.

Utilising the indicators as a qualitative assessment, a profile can be constructed to indicate the area of concern and where specific interactions and strategies are required. On the six dimensions of professional wholeness each individual employee and organisation will dynamically reflect a different state of professional wholeness

The individual professional wholeness (ipw) profile and organisational professional wholeness (opw) profile are qualitative instruments to assist the manager in appraising and estimating the state of professional wholeness. Although quantitative values are used they are used not to quantify, but to describe a position on the professional wholeness continuum. To visualise a professional wholeness profile an elementary line graph is used. The reflection of a particular dimension as well as the whole picture should be considered. The individual professional wholeness profile utilises the indicators on the different dimensions for an individual employee (refer to table one). A continuum is used as the instrument for appraising the professional wholeness profile. An individual employee marks a point on the continuum against an indicator to signify his/her perception and experiences in relation to the professional environment.

Due to the uniqueness of individuals, some persons are more focused on one or more particular dimensions than on another. This preference to be more focused on one dimension does not necessarily mean a minimal reflection of individual professional wholeness on the other dimensions. An individual's inherent focus can be high on all the dimensions. There is no judgement on the appropriateness or the wrong or right of one dimension in favour of another. Each one of these orientations is essential to form the whole and therefore the inherent talents of persons must be enhanced and must not be suppressed. It basically confirms the fact that each one of us is unique with unique talents.
The six orientations are described as proto-types according to the professional wholeness dimensions. The orientations are not mutually exclusive, although for theoretical purpose they are discussed as such. The various orientations are essential for respectively promoting. restoring and maintaining each of the wholeness dimensions. Excessive emphasis on one dimension only will lead to dissonance in another dimension. The manager's concern is the facilitation of individual and organisational professional wholeness. Understanding the various orientations is, however, important to the manager in his understanding of himself and in order to harmonise the interactional process on all the dimensions.

The physical orientation reflects exceptional proficiency in structural/physical aspects. High energy levels and activity are reflected. In his/her interaction with others the person with this orientation concentrates on structural and physical aspects. The focus is on hygiene, budgetary control, environmental safety and security.

When a person has an exceptionally high social focus his/her inherent talents are a high proficiency in interpersonal relationships and skills. This person functions particularly well within a team, co-operates and participates easily and is generally very popular with colleagues. The person who has an exceptionally high spiritual focus has an irreproachable sense of justice and fairness. His/her talents are in loyalty and faithfulness. This person is also extremely honest, reliable, accountable and generally acts as the guardian of the organisational conscience. The person with an intense focus on the intellectual dimension has exceptional logical and rational abilities. His/her special talents are in analysis and in being systematic. A great deal of attention is given to detail as well as to visualise the overall picture.

The person with an intense orientation on the emotional dimension feels very strongly and identifies with emotional issues and very expressive in making a point. His/her exceptional talents are empathy for and compassion with others. The major distinctive ability of the person with an intense focus on the volitional 
Table 2 Organisational professional wholeness indicators

\begin{tabular}{|c|c|}
\hline $\begin{array}{l}\text { PHYSICAL } \\
\text { INDICATORS }\end{array}$ & $\begin{array}{l}\text { SPIRITUAL } \\
\text { INDICATORS }\end{array}$ \\
\hline maximal & maximal \\
\hline $\begin{array}{c}\text { neat } \\
\text { clean } \\
\text { adequacy } \\
\text { order } \\
\text { conservation } \\
\text { safety } \\
\text { protection } \\
\text { prosperous }\end{array}$ & $\begin{array}{c}\text { fairness } \\
\text { obedience } \\
\text { compliance } \\
\text { righteousness }\end{array}$ \\
\hline minimal & minimal \\
\hline $\begin{array}{c}\text { injuries } \\
\text { destruction } \\
\text { wastage } \\
\text { damage } \\
\text { chaos } \\
\text { danger } \\
\text { violence } \\
\text { insufficiency } \\
\text { havoc } \\
\text { fatigue } \\
\text { vandalism } \\
\text { laziness } \\
\text { materialism }\end{array}$ & $\begin{array}{c}\text { sabotage } \\
\text { submission } \\
\text { corruption } \\
\text { prejudice } \\
\text { grievances } \\
\text { malpractice } \\
\text { crime } \\
\text { hypocrisy } \\
\text { deceit } \\
\text { injustice } \\
\text { intimidation } \\
\text { misconduct }\end{array}$ \\
\hline
\end{tabular}

orientation is his/her willpower to succeed. This person has a great deal of determination, drive and ambition and does not hesitate to make decisions.

The organisational professional profile is compiled, based on the average of a collection of instruments, completed by a group of employees about their perceptions and experiences of the professional wholeness status of the organisation. The professional wholeness dimensions are applied, although the indicators (compare table two) are marginally different to that of the individual employee indicators in that they are applicable to a situation, group or organisation.

\section{Conclusion And Recommendations}

The model can be applied to nurse management in the public as well as private sectors. In the public sector where the emphasis is on the superiority of the position - although unacceptable - the application is possible by bringing about

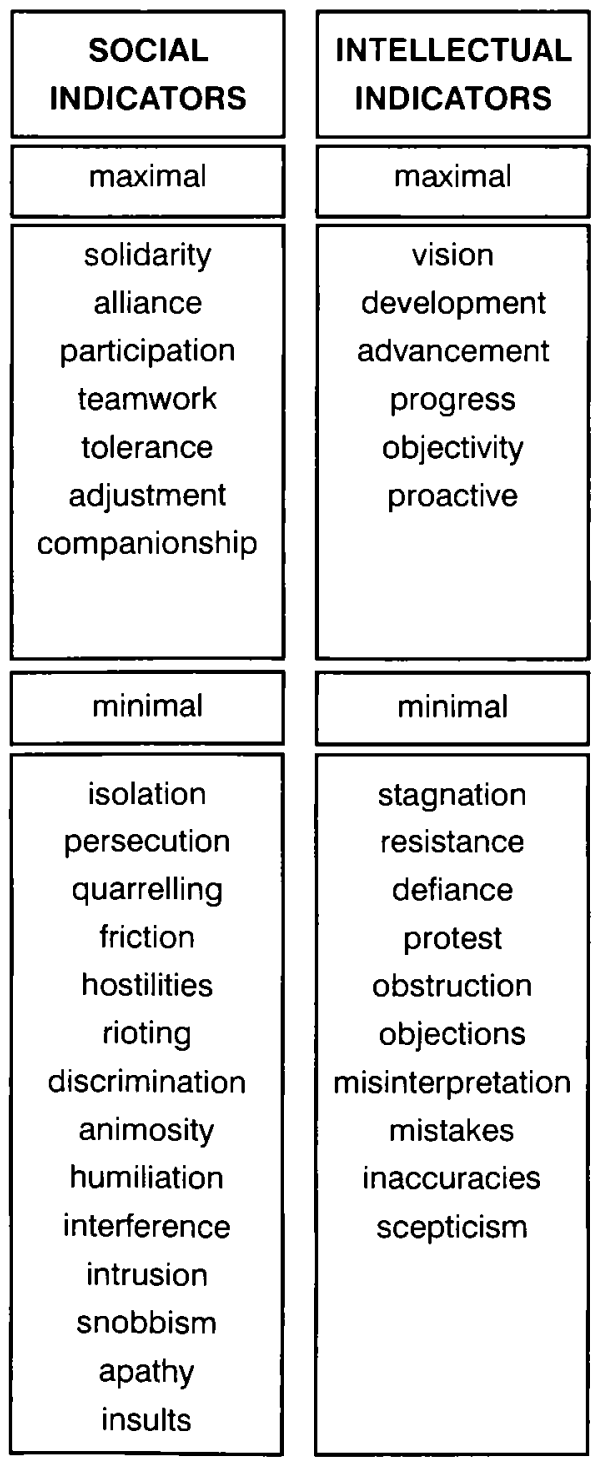

a change in viewpoint as the management model for professional wholeness does not advocate disorder and disobedience. Although the basic motive of the model is not to increase profits it can be predicted that the improved quality of service, as generated by this model, will enhance the competitive edge of the private sector.

Constant refinement and functional applications are presently being researched through peer group review. A manual for professional wholeness management is in the process of being compiled. The reliability and validity of the professional wholeness continuums are currently under review. Interest in the model has also been expressed by consultants in general management especially because of the models relevancy and potential to the service industry in general.

\begin{tabular}{|c|c|}
\hline $\begin{array}{l}\text { EMOTIONAL } \\
\text { INDICATORS }\end{array}$ & $\begin{array}{l}\text { VOLITIONAL } \\
\text { INDICATORS }\end{array}$ \\
\hline maximal & maximal \\
\hline $\begin{array}{c}\text { peace } \\
\text { tranquillity } \\
\text { support } \\
\text { sincerity } \\
\text { compassion } \\
\text { trust }\end{array}$ & $\begin{array}{c}\text { stability } \\
\text { focused } \\
\text { endurance } \\
\text { inspiration } \\
\text { rapport } \\
\text { consensus } \\
\text { compromise }\end{array}$ \\
\hline minimal & minimal \\
\hline $\begin{array}{l}\text { conflict } \\
\text { complaints } \\
\text { brutality } \\
\text { tyranny } \\
\text { rejection } \\
\text { antagonism } \\
\text { exploitation } \\
\text { suspicion }\end{array}$ & $\begin{array}{c}\text { oppression } \\
\text { mutiny } \\
\text { boredom } \\
\text { disappointment } \\
\text { apposition } \\
\text { deterioration } \\
\text { confusion } \\
\text { idleness } \\
\text { disruption } \\
\text { negligence } \\
\text { domination }\end{array}$ \\
\hline
\end{tabular}

\section{Acknowledgement}

This article is based on research completed by Marie de Villiers for her Ph.D. dissertation at the Department of Nursing Science, Rand Afrikaans University in 1992-1993. The two coauthors were her supervisors. 


\section{References}

BANDMAN, L. \& BANDMAN, B. 1988. Critical thinking in Nursing. Norwalk : Appleton and Lange.

BEER, M. 1980. A social systems model for organisation development. (In Cummings, TG ed. Systems theory for organization development. New York : Wiley \& Sons.)

DICKOFF, J., JAMES, P., \& WIEDENBACH, E. 1968. Theory in a practice discipline. Part 1. Practice orientated theory. Nursing Research, 17(5): 415-435.

DI VINCENTI, M. 1989. Administering nursing service. Pretoria : Academica.

DOUGLAS, L.M. 1988. The effective nurse leader. St. Louis : Mosby.

FAYOL, H. 1947. General industrial management (In Pugh, D.S., ed. Organisation theory, selcted readings. England : Penguin Books.)

GILLIES, D.E. 1989. Nursing management, a system approach. Philadelphia : WB Saunders.

HARDY, ME. 1973. The nature of theiries. (/n Theoretical foundations for nursing. New York: MSS Information Systems.)

LIKERT, R. 1961. The principle of supportive relationships. (In Pugh, D.S., ed. Organisation theory selected readings. England : Penguin Books.)

MILES, R.E. 1975. Theories of management: implications for organizational behavior and development. New York : McGraw -Hill.

MOUTON, J. \& MARAIS, H.C. 1991. Basic concepts in the methodology of social science. Pretoria : Human Science Research Council.

MULLER, M.E. \& COETZEE, L. $1990 . \quad$ Verslag oor die ondersoek na die verpleegberoep. Pretoria : Suid-Afrikaanse Verpleegstersvereniging.

ORAL ROBERTS UNIVERSITY ANNA VAUGHN SCHOOL OF NURSING. 1990. Self Study Report, submitted to the Council of Baccalaureate and Higher Degree Programs, National League for Nursing, Volume 1, Narrative by criteria. Tulsa, Oklahoma: Oral Roberts University Anna Vaughn School of Nursing: 136142.

POGGENPOEL, M. 1989. Psychiatric nursing conceptual model: a research report. Johannesburg : Rand Afrikaans University.

PORTER O' GRADY, T. 1986. Creative nursing administration: participative management into the 20th century. Maryland: Aspen.

RAND AFRIKAANS UNIVERSITY DEPARTMENT OF NURSING SCIENCE. 1991. Nursing for the Whole Person Theory. Johannesburg : Rand Afrikaans University.

ROBEY, D. 1982. Designing organizations: a macro perspective. Ontario : Irwin.
STRATTON, W.E. \& FLYNN, W.R. 1980. Ecological theory and organization development. (In Cummings, T.G., ed. Systems theory for organization development. New York: Wiley \& Sons.)

VOGT, J.F., COX, J.L., VELTHOUSE, B.A., \& THAMES, B.H. 1983. Retaining professional nurses: a planned process. St. Louis : CV Mosby.

VROOM, V.H. 1974. A normative model for decision making. (In Pugh, D.S., ed. Organisation theory: selected readings. England: Penguin Books.)

WALEK, O.Z . 1979. Loss of control as it relates to nurses' job satifaction and turnover: an organizational study. (D. Phil. dissertation). California : University of California.

WALKER, L.O. \& AVANT, K.C. 1983. Starategies of theory construction in nursing. Connecticut : Appleton-Century-Crofts.

WANDELT, M.A. \& STEWART, D.S. 1975. Nursing competencies rating scaSlater le. New York : Appleton-CenturyCrofts.

WEBER, M. 1947. The theory of social and economic organisation. (In Pugh, D.S., ed. Organisation theory: selected readings. England : Penguin Books.)

WILSON, H.S. 1989. Research in nursing. California : Addison Wesley.

WILSON, J. 1987. Thinking with concepts. New York : Cambridge University Press. 